\title{
Attractancy of Synthetic Compounds Related to Methyleugenol for Oriental Fruit Fly and Melon Fly*
}

\author{
Sung-Lien LeE and Yuh-Lin CHEN** \\ Department of Applied Zoology, Taiwan Agricultural Research Institute, \\ Taipei, Taiwan, Republic of China \\ **Department of Agricultural Chemistry, National Taiwan University, \\ Taipei, Taiwan, Republic of China
}

(Received October 25, 1976)

\begin{abstract}
Sixty compounds structurally related to methyleugenol, which is believed to be one of the most powerful attractant for male oriental fruit fly (Dacus dorsalis Hendel) were tested for their attractiveness against this insect with a specially designed olfactometer. No definite correlation between the structure and activity was found, but some tendency was observed. Methylisoeugenol, veratric acid, methyleugenol and eugenol were the most effective attractants among these compounds tested. A part of these synthetic compounds were also tested against melon fly (Dacus cucurbitae Coquillett). None of the chemicals tested was found to be significantly attractive for this insect.
\end{abstract}

\section{INTRODUCTION}

The attractiveness of methyleugenol to male oriental fruit fly was first reported in 1915 by Howlett. ${ }^{1)}$ This compound is still considered to be one of the most powerful attractant for male oriental fruit fly. ${ }^{2-4)}$ In 1963, Beroza and Green compiled the Agriculture Handbook in which 4,108 compounds were tested as insect attractants and oriental fruit fly and melon fly were included as test insects in this literature. ${ }^{4)}$

In order to study the effect of changes in structure on attractiveness to the fruit fly and to seek further for compound of higher activities, 60 compounds structurally related to methyleugenol were examined for their attractiveness against oriental fruit fly. A part of these synthetic compounds, 27 out of 60 , were also tested against melon fly.

* A part of this work was presented at the International Symposium and Workshop on Fruit Flies at Honolulu, Hawaii, Dec. 6, 1976.

\section{MATERIALS AND METHODS}

Among 60 compounds tested, 42 compounds were synthesized in the laboratory. The methods of synthesis together with their structures, melting points or boiling points and yields of these compounds were reported in the previous work. ${ }^{5)}$ Eighteen compounds were procured from the commercial products and purified either by redistillation or by recrystallization.

The screening tests against oriental fruit fly for their attractiveness were performed in the Fruit Fly Research Unit, Taiwan Citrus Protection Research Laboratory, Hsinchu, Taiwan. In the laboratory screening test, a specially designed olfactometer was introduced with 2,000-2,500 laboratory reared oriental fruit flies. The olfactometer (Fig. 1) is an octagonal cage, 3 feet high and 2.5 feet wide, equipped with 8 glass flask (without bottom) traps. In each flask trap was placed an one-inch length of cotton roll on which a $50 \%$ of candidate lure in alcohol solution was saturately absorbed. Three candidate lures with one alcohol control were tested simultaneously and a pair of the 


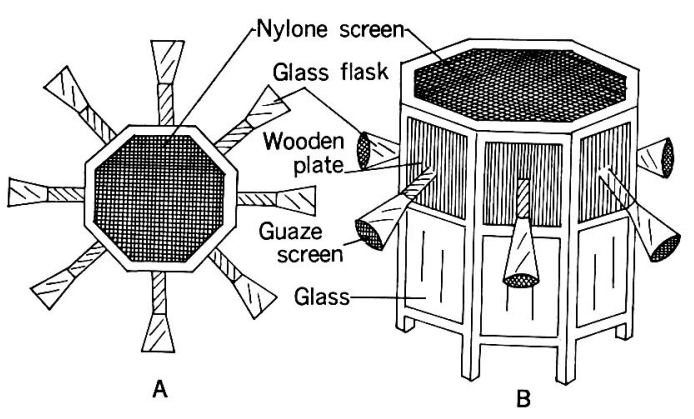

Fig. 1 Olfactometer for screening test. A. Dorsal view, B. Side view.

same compound was put at an opposite angle. Experiments were done in 3 replicates with each compound. During the course of test, the olfactometer was rotated at every $30 \mathrm{~min}$ for one angle to eliminate any positional advantage. After $4 \mathrm{hr}$, the numbers of fruit flies caught were counted and the relative attractiveness was subsequently calculated according to the following formula:
Total number of fruit flies caught in

$$
\begin{aligned}
& \begin{array}{l}
\text { Relative } \\
\text { attractiveness }
\end{array}=\frac{\text { test lure trap }}{\text { Total number of }} \times 100 \\
& \text { fruit flies caught in } \\
& \text { alcohol trap }
\end{aligned}
$$

The tests of attractiveness against melon fly were carried out in a same manner with that of the method performed for oriental fruit fly.

\section{RESULTS AND DISCUSSION}

As a fundamental structure, all of these compounds have at least one methoxyl group in the benzene nucleus. The results were compared to that of the above mentioned literature complied by Beroza and Green ${ }^{4}$ and tabulated as shown in Table 1. Four compounds, namely methylisoeugenol, veratric acid, methyleugenol and eugenol were found to be the most effective attractant to this insect. The strong attractiveness of veratric acid to oriental fruit fly seemed to be a new finding in this study. None of the chemicals

\begin{tabular}{|c|c|c|c|c|c|c|c|c|c|}
\hline \multirow{4}{*}{$\begin{array}{l}\text { Compd. } \\
\text { No. }\end{array}$} & \multirow{4}{*}{$\begin{array}{c}\text { Original } \\
\text { Compd. } \\
\text { No.5) }\end{array}$} & \multirow{4}{*}{$\begin{array}{c}\text { USDA } \\
\text { Item } \\
\text { No. }{ }^{4}\end{array}$} & \multirow{4}{*}{ Chemical } & \multicolumn{6}{|c|}{ Relative attractiveness } \\
\hline & & & & \multicolumn{3}{|c|}{ Oriental fruit fly } & \multicolumn{3}{|c|}{ Melon fly } \\
\hline & & & & \multicolumn{3}{|c|}{ USDA } & \multicolumn{3}{|c|}{ USDA } \\
\hline & & & & $(\%)$ & & Class**4) & $(\%)$ & Class* & \\
\hline 1 & 51 & 2610 & Methylisoeugenol & 1396 & 4 & 3 & 19 & 1 & - \\
\hline 2 & 16 & - & Veratric acid & 465 & 4 & - & 96 & 2 & - \\
\hline 3 & 50 & 2608 & Methyleugenol & 441 & 4 & 3 & 48 & 1 & - \\
\hline 4 & 44 & 2501 & Eugenol & 407 & 4 & 3 & 88 & 2 & - \\
\hline 5 & 2 & 2606 & Veratrol & 324 & 4 & 2 & 26 & 1 & 1 \\
\hline 6 & 34 & 499 & $o$-Anisic acid butyl ester & 319 & 4 & 2 & - & - & - \\
\hline 7 & 15 & 84 & $p$-Anisic acid & 314 & 4 & 1 & 211 & 4 & - \\
\hline 8 & 35 & 2511 & Guaiacol & 227 & 4 & 3 & 55 & 2 & 2 \\
\hline 9 & 32 & - & p-Methoxycinnamic acid & 226 & 4 & - & 67 & 2 & - \\
\hline 10 & 47 & 1233 & Eugenol acetate & 222 & 4 & 3 & 93 & 2 & 2 \\
\hline 11 & 37 & - & Guaiacol valerate & 186 & 3 & - & 108 & 3 & - \\
\hline 12 & 66 & - & $\begin{array}{l}\text { 4,4-Dimethoxybenzophe- } \\
\text { none }\end{array}$ & 178 & 3 & - & 106 & 3 & - \\
\hline 13 & 38 & 1301 & Guaiacol $n$-caproate & 176 & 3 & 2 & 50 & 2 & 1 \\
\hline 14 & 9 & 346 & Veratraldehyde & 176 & 3 & 3 & - & - & 2 \\
\hline 15 & 57 & - & Acetylvanillic acid & 172 & 3 & - & - & - & - \\
\hline 16 & 53 & 344 & Vanillin & 151 & 3 & 2 & 一 & - & - \\
\hline 17 & 26 & - & $p$-Acetanisidide & 143 & 3 & - & 362 & 4 & - \\
\hline 18 & 27 & 2624 & $p$-Methoxyacetophenone & 130 & 3 & 1 & 149 & 3 & 1 \\
\hline 19 & 25 & 2985 & $o$-Acetanisidide & 129 & 3 & 1 & 184 & 3 & 1 \\
\hline
\end{tabular}

Table 1 Attractancy of compounds related to methyleugenol for oriental fruit fly and melon fly. 


\begin{tabular}{|c|c|c|c|c|c|c|c|c|c|}
\hline 20 & 59 & 238 & Vanillin ethyl ether & 126 & 3 & 3 & - & - & 1 \\
\hline 21 & 36 & 1266 & Guaiacol acetate & 117 & 3 & 3 & 279 & 4 & 2 \\
\hline 22 & 31 & - & $p$-Anisalcinnamalacetone & 117 & 3 & - & - & - & - \\
\hline 23 & 29 & 2241 & $o$-Anisalacetone & 112 & 3 & 2 & - & - & 1 \\
\hline 24 & 23 & 3029 & 2,5-Dimethoxyaniline & 101 & 3 & 2 & - & - & 1 \\
\hline 25 & 64 & - & $\begin{array}{c}\text { 1,1-Bis ( } p \text {-methoxyphenyl) } \\
\text { 2,2,2-tricholoroethane }\end{array}$ & 101 & 3 & - & - & - & - \\
\hline 26 & 67 & - & $\begin{array}{l}\text { 1, } 1 \text {-Bis }(p-\text { methoxyphenyl) } \\
\text { ethane }\end{array}$ & 101 & 3 & - & - & - & - \\
\hline 27 & 14 & 81 & $m$-Anisic acid & 100 & 3 & 1 & - & - & 1 \\
\hline 28 & 49 & - & Eugenol cinnamate & 96 & 2 & - & - & - & - \\
\hline 29 & 40 & - & Guaiacol cinnamate & 87 & 2 & - & - & 一 & - \\
\hline 30 & 52 & 2106 & Anethole & 86 & 2 & 1 & 20 & 1 & - \\
\hline 31 & 58 & 176 & Vanillic acid & 86 & 2 & 2 & - & - & 1 \\
\hline 32 & 46 & - & $o$-Eugenol & 80 & 2 & - & - & - & - \\
\hline 33 & 24 & - & $o$-Dianisidine & 76 & 2 & - & - & - & - \\
\hline 34 & 21 & 3039 & $o$-Anisidine & 73 & 2 & 1 & 56 & 2 & - \\
\hline 35 & 17 & 93 & $\begin{array}{l}3,4,5 \text {-Trimethoxybenzoic } \\
\text { acid }\end{array}$ & 71 & 2 & 1 & - & - & 1 \\
\hline 36 & 42 & 2564 & $p$-Methoxyphenol & 65 & 2 & 2 & - & - & 2 \\
\hline 37 & 41 & 2157 & Guaiacol allyl ether & 59 & 2 & 1 & - & - & 1 \\
\hline 38 & 63 & - & Acetylferulic acid & 57 & 2 & - & - & - & - \\
\hline 39 & 54 & 345 & $o-$ Vanillin & 56 & 2 & 2 & - & - & 1 \\
\hline 40 & 45 & 2519 & Isoeugenol & 52 & 2 & 3 & 106 & 3 & - \\
\hline 41 & 60 & 2240 & Vanillalacetone & 49 & 1 & 2 & - & - & 1 \\
\hline 42 & 4 & 2174 & $p$-Dimethoxybenzene & 48 & 1 & 1 & - & - & 1 \\
\hline 43 & 33 & - & $o-$ Methoxycinnamic acid & 47 & 1 & - & - & - & 一 \\
\hline 44 & 10 & - & $o$-Methoxybenzyl alcohol & 47 & 1 & - & - & - & - \\
\hline 45 & 61 & - & Vanillalacetone acetate & 45 & 1 & - & - & - & - \\
\hline 46 & 28 & - & $p$-Methoxybenzophenone & 44 & 1 & - & - & - & - \\
\hline 47 & 3 & 2173 & $m$-Dimethoxybenzene & 41 & 1 & 2 & 48 & 1 & 1 \\
\hline 48 & 18 & 2124 & $o$-Methylanisole & 40 & 1 & 1 & 52 & 2 & 1 \\
\hline 49 & 11 & 2132 & Anisyl alcohol & 39 & 1 & 2 & 47 & 1 & - \\
\hline 50 & 48 & - & Eugenol benzoate & 33 & 1 & - & - & - & - \\
\hline 51 & 62 & - & Ferulic acid & 29 & 1 & - & - & - & - \\
\hline 52 & 8 & 249 & $p$-Anisaldehyde & 19 & 1 & 1 & 23 & 1 & 一 \\
\hline 53 & 12 & - & $\begin{array}{l}\text { 4-Methyl-2-methoxy- } \\
\text { benzyl alcohol }\end{array}$ & 18 & 1 & - & - & - & - \\
\hline 54 & 7 & 246 & $o$-Anisaldehyde & 18 & 1 & 1 & 5 & 1 & 1 \\
\hline 55 & 22 & 3042 & $p$-Anisidine & 17 & 1 & 1 & - & - & - \\
\hline 56 & 1 & 2109 & Anisole & 16 & 1 & 1 & 7 & 1 & - \\
\hline 57 & 20 & 2125 & p-Methylanisole & 15 & 1 & 1 & 12 & 1 & - \\
\hline 58 & 13 & 82 & $o$-Anisic acid & 15 & 1 & 1 & - & - & 1 \\
\hline 59 & 65 & - & $\begin{array}{l}\text { 1,1-Bis }(p \text {-methoxyphenyl) } \\
2,2 \text {-dichloroethylene }\end{array}$ & 15 & 1 & - & - & - & - \\
\hline 60 & 19 & 2123 & $m$-Methylanisole & 11 & 1 & 1 & 37 & 1 & 1 \\
\hline
\end{tabular}

* Attractancy index for

Class 1: Relative attractiveness less than 50\%. Class 3: Relative attractiveness from 100 to $199 \%$. Class 2: Relative attractiveness from 50 to $99 \%$. Class 4 : Relative attractiveness greater than $200 \%$. ** Attractancy index for

Class 1: Less than 11 for males, less than 6 for females.

Class 2: From 11 to 50 for males, from 6 to 50 for females.

Class 3: Greater than 50 for males, greater than 50 for females.

tested was found to be significantly effective against melon fly.

Although there is no definite correlation between the structure and activity was found, conversion of allyl group to propenyl group by isomerization from methyleugenol (Compd. 
3) to methylisoeugenol (Comp. 1) increased the activity significantly. But from eugenol (Compd. 4) to isoeugenol (Compd. 40), this phenomenon was not observed in spite of the close similarity. Additional methoxyl group at ortho position in the benzene nucleus seemed to be useful in requirement of attractancy as shown in methylisoeugenol (Compd. 1), veratric acid (Compd. 2), methyleugenol (Compd. 3) and veratrole (Compd. 5). But one more addition of methoxyl group in veratric acid (3,4-dimethoxybenzoic acid) (Compd. 2) to give 3,4,5-trimethoxybenzoic acid (Compd. $35)$ greatly decreased the activity.

In general, the results of the attractiveness were well agreed to that of the data reported in the literature, ${ }^{4)}$ even though 22 compounds were not included in the report.

Methyleugenol still seemed to be an effective attractant available at present time. This compound has been officially recommended for the control of male oriental fruit fly in the citrus orchard in Taiwan for many years. Especially it is important for the evaluation of the population of this harmful insect in the field.

The leaves and stems of sweet basil, Ocimum basilicum L. (Labiatae) were found to be attractive to male oriental fruit fly and occasionally used as an attractant by the local people in the field in Taiwan. The active constituents of this plant were isolated and identified as methylchavicol and methyleugenol by the authors. ${ }^{6)}$ Kawano et al. also reported that the existence of methyleugenol in the blossom of golden shower, Cassia fistula L. (Leguminosae) was considered to be the cause of its attractiveness to oriental fruit fly. ${ }^{7}$ ) No connection could be derived regarding the attractiveness between oriental fruit fly and melon fly with these chemicals.

\section{ACKNOWLEDGEMENTS}

The authors wish to express their sincere thanks to Dr. H. Y. Liu, The Joint Commission on Rural Reconstruction, for his assistance and cooperation.

\section{要約}

メチルオイゲノールは，現今でも雄のミカンコミバェ (Dacus dorsalis Hendel) に対して最も有力な誘引戍で あるとされている．化学構造とこの害虫に対する誘引作 用との関係を明らかにし，より有効なミカンコミバエ誘 引凨を見つける目的でメチルオイゲノールと関連のある 芳香族化合物 60 種を試験材料とし，この試験のために とくに設計したミバエ誘引試験装置を用いて効力を試験 した。結局，化学構造と誘引作用との間に明確な関係を 見つけ出すととはできなかったが，若干の傾向の存在を 認めることができた，供試薬戍の中で最も効力の強かっ たものは methylisoeugenol, veratric acid, methyleugenol および eugenolであった。 veratric acidがミ カンコミバエに対して強力な誘引作用を持っていること は従来知られていなかったようである。一部の化合物に ついては, ウリミバェ (Dacus cucurbitae Coquillett) に対する誘引作用を試験したがとくに強力なものは得ら れなかった。

\section{REFERENCES}

1) F. M. Howlett: Bull. Ent. Res. 6, 297 (1915)

2) L. F. Steiner: J. Econ. Entomol. 45, 241 (1952)

3) W. B. Barthel, N. Green, I. Keiser \& L. F. Steiner: Science 126, 654 (1957)

4) M. Beroza \& M. Green (Compiler): Materials tested as insect attractants "Agriculture Handbook," No. 239, Agr. Res. Ser. U.S. Dept. Agric., pp. 148, 1963

5) Y. L. Chen, H. M. Cheng \& S. C. Tsai: $J$. Chinese Agric. Chem. Soc. Spec. Issue, 1 (1965)

6) Y. L. Chen, J. Y. Wu \& S. L. Lee: J. Chinese Agric. Chem. Soc. Spec. Issue, 47 (1970)

7) Y. Kawano, W. C. Mitchell \& H. Matsumoto: J. Econ. Entromol. 61, 986 (1968) 